\title{
The relationship between first-trimester pregnancy-associated plasma protein-A levels and intrapartum fetal distress development
}

\author{
Ayşe Filiz Avşarr ${ }^{1}$ Elçin İşlek Seçen², Gülin Feykan Yeğin Akçay² ${ }^{2}$ Hüseyin Levent Keskin², Emre Erdem Taş ${ }^{1}$, \\ Ahmet Ferit Dalgaci ${ }^{2}$ \\ ${ }^{1}$ Department of Gynecology and Obstetrics, Yuldirm Beyazit University School of University, Ankara, Turkey \\ ${ }^{2}$ Department of Gynecology and Obstetrics, Atatürk Training and Research Hospital, Ankara, Turkey
}

\begin{abstract}
Objective: To investigate the relationship between the development of intrapartum fetal distress and serum pregnancy-associated plasma protein-A (PAPP-A) levels measured during first-trimester aneuploidy screening tests.

Material and Methods: This retrospective study included 283 uncomplicated pregnancies that resulted in full-term live births via spontaneous labor or with the induction by oxytocin. Cases were divided into two groups based on whether their first-trimester PAPP-A multiple of the median (MoM) levels were $\leq 0.5$ (Group $1, n=75$ ) or $>0.5$ (Group 2, $n=208$ ). As primary end points, the rate of cesarean section $(\mathrm{C} / \mathrm{S}$ ), the rate of $\mathrm{C} / \mathrm{S}$ due to fetal distress, and the umbilical artery blood $\mathrm{pH}$ values in cases of $\mathrm{C} / \mathrm{S}$ for fetal distress were compared between the two groups. Statistical analyses were performed using the Chi-square test and independent samples t-test. $\mathrm{P} \leq 0.05$ were considered statistically significant. Results: The mean gestational age at birth and the birth weights were significantly lower in Group 1 than in Group 2 ( $p=0.002$ and $p=0.007$, respectively). Although the rate of $\mathrm{C} / \mathrm{S}$ was similar between the groups $(\mathrm{p}=0.823)$, the rate of $\mathrm{C} / \mathrm{S}$ due to fetal distress was significantly higher in Group 1 than in Group $2(68.4 \%$ vs. $42 \%$, respectively; $\mathrm{p}=0.050)$ and the mean umbilical artery blood $\mathrm{pH}$ value for $\mathrm{C} / \mathrm{S}$ deliveries indicated by fetal distress was lower $(\mathrm{p}=0.048)$ in Group 1 than in Group 2. When the mode of delivery was analyzed according to the application of labor induction, both the $\mathrm{C} / \mathrm{S}$ delivery rates $(31.6 \%$ in Group 1 and $31.7 \%$ in Group $2 ; \mathrm{p}=0.992)$ and $\mathrm{C} / \mathrm{S}$ delivery rates due to fetal distress $(66.7 \%$ in Group 1 and $46.2 \%$ in Group 2; $\mathrm{p}=0.405$ ) were similar in both groups.

Conclusion: Low PAPP-A levels $(\leq 0.5 \mathrm{MoM})$ in the first trimester are associated with the risk of intrapartum fetal distress development and the likelihood of C/S for fetal distress. Nonetheless, this risk is not affected by labor induction. (J Turk Ger Gynecol Assoc 2016; 17: 139-42)

Keywords: Cesarean section, fetal distress, pregnancy-associated plasma protein A

Received: 15 February, 2016 Accepted: 25 July, 2016
\end{abstract}

\section{Introduction}

Pregnancy-associated plasma protein A (PAPP-A) is one of the parameters in the first-trimester screening test that is used as a biochemical marker to detect aneuploidy in the early weeks of gestation (1). PAPP-A can be detected in the maternal blood 28 days after implantation in singleton pregnancies. The serum PAPP-A level starts to increase during the first trimester, doubling every 3 to 4 days. The rate of increase is gradual until week 36, after which it accelerates, and the maximum serum PAPP-A levels are reached at term (2).

It is thought that PAPP-A released from trophoblastic tissues at abnormal levels early during gestation affects fetal growth negatively by impairing trophoblastic invasion of the decidua, causing abnormal placentation and other pregnancy complications (3). A low PAPP-A concentration is a powerful indicator of potential pregnancy complications, includ- ing preeclampsia, intrauterine developmental retardation, gestational hypertension, fetal death, oligohydramnios, and preterm birth (4-6). Because PAPP-A levels during pregnancy are associated with obstetric complications, as well as abnormal placentation, it is thought that fetuses born to mothers with low maternal PAPP-A levels do not tolerate labor stress and also could be more likely to develop intrapartum fetal distress (7).

In this study, we compared the rate of emergency cesarean section $(\mathrm{C} / \mathrm{S})$ due to fetal distress and the umbilical arterial blood gas levels in patients with normal or low PAPP-A levels in the first trimester.

\section{Material and Methods}

We conducted a retrospective examination of 359 cases of singleton pregnancies in which the first-trimester screening for aneuploidy had been performed in our pregnancy out- 
patient clinic between June 2012 and January 2013. The local ethics committee of the hospital approved the study and each patient signed the informed consent.

In all cases, the mothers were followed for the duration of their pregnancies. Crown-rump length (CRL) measurements (range: 45-84 mm) were obtained and the nuchal translucency (NT) test was performed on the live singleton fetuses confirmed to be between 11 weeks and 13 weeks and 6 days old by ultrasound. The serum levels of PAPP-A and free hCG were tested in the maternal blood and adjusted according to the maternal weight, insulin-related diabetes, and smoking habits. Multiple of the median (MoM) values were calculated.

Cases with abnormal fetal karyotypes, pregnancy complications (preterm delivery, pregnancy induced hypertension/preeclampsia, gestational diabetes, intrauterine growth restriction, and placental abruption) and systemic diseases (chronic hypertension, type 1 and type 2 diabetes mellitus) or in which the mothers elected to have $\mathrm{C} / \mathrm{S}$ deliveries (due to past $\mathrm{C} / \mathrm{S}$ or presentation abnormalities) were excluded from the study $(\mathrm{n}=76)$.

The final cohort included the results from 283 cases in which first-trimester screening for fetal aneuploidy had been conducted and also the delivery had occurred at term ( $\geq 37$ weeks gestation) following either spontaneous labor or labor induction with oxytocin for cases in which the gestation reached beyond the $41^{\text {st }}$ week without the spontaneous onset of labor, or there was early membrane rupture, oligohydramnios, or non-reassuring fetal well-being tests.

The cases were divided into two groups based on their first-trimester PAPP-A multiples of their median (MoM) values as $\leq 0.5$ MoM (Group 1) or >0.5 MoM (Group 2).

The demographic features, birth weight, gender, delivery modes, and indications for $\mathrm{C} / \mathrm{S}$ were recorded, and the umbilical arterial blood gas $\mathrm{pH}$ values were compared between the two groups in cases where fetal distress had developed. Fetal distress was determined using fetal monitoring based on the American Congress of Obstetricians and Gynecologists intrapartum fetal heart rate trace management protocol (8). C/S decision was made by the same authors (AFA and HLK). According to the mentioned management protocol, category II (intermediate) cases were evaluated and under surveillance, and if the fetal heart rate (FHR) accelerations were absent and absent/minimal FHR variability occurred and did not improve, or FHR tracing progressed to a category III (abnormal) pattern, then delivery was considered. General anesthesia was administered in all the cases in which $\mathrm{C} / \mathrm{S}$ was performed because of fetal distress. There was not any instrumental operative delivery.

Statistical analyses were performed using SPSS ver. 21.0 (IBM Corp.; California, USA). Descriptive characteristics were expressed as numbers and percentages, the mean \pm standard deviation (SD) (minimum-maximum), or as the median (interquartile ranges [IQRs]) (minimum-maximum) according to whether the variables were distributed as normal using the Shapiro-Wilk test. Inter-group comparisons were made using the Pearson Chi-square test for the categorical variables, and with the independent samples t-test for continuous data. Statistical significance was defined as $\mathrm{p} \leq 0.05$.

\section{Results}

PAPP-A levels were $\leq 0.5$ MoM in 75 (26.5\%) cases (Group 1) and $>0.5$ MoM in 208 (73.5\%) subjects (Group 2). The mean PAPP-A levels was $0.38 \pm 0.10 \mathrm{MoM}$ for Group 1 and $1.14 \pm 0.63$ MoM for Group $2(\mathrm{p}<0.001)$.

The age, gravidity, and parity were similar among the groups ( $>0.05$ ). (Table 1) The mean gestational age at birth and the birth weights were significantly lower in Group 1 than Group 2 $(\mathrm{p}=0.002$ and $\mathrm{p}=0.007$, respectively).

The cesarean delivery rate was $24.4 \%(69 / 283)$ in all the subjects. Although the rate of $\mathrm{C} / \mathrm{S}$ were similar among the groups $(\mathrm{p}=0.823)$, the rate of $\mathrm{C} / \mathrm{S}$ due to fetal distress was significantly higher in Group 1 (68.4\% (13/19) vs 42\% (21/50), $\mathrm{p}=0.050)$ (Table 1). In addition, the mean umbilical artery blood gas $\mathrm{pH}$ value for $\mathrm{C} / \mathrm{S}$ deliveries indicated by fetal distress was also significantly lower in Group $1(p=0.048)$. According to the ACOG management protocol, the category III (abnormal) FHR pattern rate was $30.8 \%(4 / 13)$ in Group 1 and 33.3\% (7/21) in Group $2(\mathrm{p}=0.877)$. The induction of labor was applied in 19 (25.3\%) subjects in Group 1 and in 41 (19.7\%) subjects in Group 2 and the rate of labor induction were similar between the groups $(p=0.307)$. When the mode of delivery was analyzed according to applying labor induction, both $\mathrm{C} / \mathrm{S}$ delivery rates ((6/19 (31.6\%) in Group $1,13 / 41(31.7 \%)$ in Group $2 ; \mathrm{p}=0.992)$ ) and the rate of $\mathrm{C} / \mathrm{S}$ delivery due to fetal distress ((4/6 (66.7\%) in Group 1, 6/13 (46.2\%) in Group $2 ; \mathrm{p}=0.405)$ ) were not different in both groups.

\section{Discussion}

PAPP-A, which was first obtained from the plasma of pregnant women in 1974, is a protein released from the placenta, and its concentration in maternal blood reflects placental activity $(9,10)$. PAPP-A is a specific protease for insulin-like growth factor binding protein-4 (IGFBP-4), and thus plays a role in fetal growth and the development and many physiopathologic events related to IGF-1 and -2 (11). Furthermore, it was found that PAPP-A plays an exclusive role in the autocrine and paracrine regulation of the trophoblastic invasion of the decidua $(12,13)$. Low PAPP-A levels are thought to be attributable to sequestration by binding proteins for free IGFs, and this can negatively affect fetal growth and cause obstetric complications $(4,12)$.

Ucella et al. (7) found that the rate of non-elective $\mathrm{C} / \mathrm{S}$ deliveries indicated by fetal distress was higher among mothers with low PAPP-A levels (16.2\%) than among mothers with normal PAPP-A (7.9\%) levels. Thus, they suggested that low PAPP-A levels may be not only related to antenatal complications (preeclampsia, intrauterine growth retardation, preterm delivery, and loss of pregnancy), but also may be a risk factor for acute intrapartum fetal distress related to abnormal placentation and placental dysfunction, leading to more emergency C/S deliveries (7).

In this study, we investigated whether fetal distress developed more frequently during labor in cases with low maternal PAPP-A levels in the first trimester and examined the umbilical arterial blood gas levels to evaluate whether there was an indirect correlation between low PAPP-A levels and the placental reserve during active labor. 
Table 1. Demographic features and delivery results in groups based on PAPP-A levels

\begin{tabular}{|c|c|c|c|c|}
\hline \multirow{2}{*}{ Parameter } & & \multicolumn{2}{|c|}{ PAPP-A } & \multirow[b]{2}{*}{$\mathbf{p}$} \\
\hline & & $\begin{array}{l}\leq 0.5 \text { MoM } \\
\quad(n=75)\end{array}$ & $\begin{array}{l}>0.5 \text { MoM } \\
(n=208)\end{array}$ & \\
\hline \multicolumn{2}{|c|}{ Maternal age, years* } & $27.1 \pm 5.1(18-40)$ & $26.6 \pm 5.1(18-42)$ & 0.433 \\
\hline \multicolumn{2}{|c|}{ Gravidity, $\mathrm{n}^{* *}$} & $2(2)(1-5)$ & $2(2)(1-9)$ & 0.766 \\
\hline \multicolumn{2}{|l|}{ Parity, $\mathrm{n}^{* *}$} & $1(1)(0-3)$ & $1(1)(0-3)$ & 0.120 \\
\hline \multicolumn{2}{|c|}{ Gestational age at delivery, weeks* } & $\begin{array}{c}38.3 \pm 4.2 \\
(37.1-41.5)\end{array}$ & $\begin{array}{c}39.3 \pm 1.6 \\
(37.0-42.1)\end{array}$ & 0.002 \\
\hline \multicolumn{2}{|c|}{ Mean birth weight, $\mathrm{g}^{*}$} & $\begin{array}{l}3213( \pm 515) \\
(2190-4310)\end{array}$ & $\begin{array}{l}3377( \pm 494) \\
(2180-5010)\end{array}$ & 0.007 \\
\hline \multirow[t]{2}{*}{ Infant gender, $\mathrm{n}$} & Male & 37 & 109 & \multirow{2}{*}{0.136} \\
\hline & Female & 38 & 99 & \\
\hline \multicolumn{2}{|c|}{$\mathrm{C} / \mathrm{S}$ delivery rate, $\mathrm{n}(\%)$} & $19(25.3 \%)$ & $50(24.0 \%)$ & 0.823 \\
\hline \multicolumn{2}{|c|}{ Labor induction, n (\%) } & $19(25.3 \%)$ & $41(19.7 \%)$ & 0.307 \\
\hline \multicolumn{2}{|c|}{$\mathrm{C} / \mathrm{S}$ rate in labor induction applying group, $\mathrm{n}(\%)$} & $6 / 19(31.6 \%)$ & $13 / 41(31.7 \%)$ & 0.992 \\
\hline \multicolumn{2}{|c|}{$\mathrm{C} / \mathrm{S}$ rate due to fetal distress in labor induction group, n (\%) } & $4 / 6(66.7 \%)$ & $6 / 13(46.2 \%)$ & 0.405 \\
\hline \multicolumn{5}{|c|}{$\begin{array}{l}* \text { Mean } \pm \text { SD (Min-Max) } \\
* * \text { Median (IQR) (Min-Max) }\end{array}$} \\
\hline
\end{tabular}

Our findings are consistent with the results reported by Ucella et al. (7) and demonstrate a higher rate of $\mathrm{C} / \mathrm{S}$ delivery because of fetal distress during active labor in cases with low PAPP-A levels $(\leq 0.5 \mathrm{MoM})$ measured during the first trimester.

Ucella et al. (7) also found that the umbilical arterial blood $\mathrm{pH}$ was significantly lower in cases where a $\mathrm{C} / \mathrm{S}$ was performed because of fetal distress in cases of low PAPP-A levels compared to cases with normal PAPP-A levels ( $\mathrm{pH}$ : 7.19 vs $\mathrm{pH}$ : 7.26, respectively). We also analyzed the umbilical cord blood $\mathrm{pH}$ immediately postpartum in cases where a $\mathrm{C} / \mathrm{S}$ was performed because of fetal distress, but we could not found any significant differences between the groups. Although the intrapartum wellbeing of the fetus during labor is generally followed with fetal electronic monitoring (FEM), in almost $50 \%$ of the fetuses where fetal distress is detected with FEM, the oxygenation of the fetus is normal (14-16).

In conclusion, PAPP-A levels between the $11^{\text {th }}$ and $14^{\text {th }}$ weeks of gestation likely reflect placental function, and the risk of developing intrapartum fetal distress and the risk of $\mathrm{C} / \mathrm{S}$ due to fetal distress are higher in cases with low ( $\leq 0.5 \mathrm{MoM}$ ) PAPP-A levels. Nonetheless, this risk is not affected by labor induction by oxytocin. The PAPP-A level measured during aneuploidy screening in the first trimester of pregnancy can help predict the development of intrapartum fetal distress. Our study is limited by its retrospective design; thus, prospective studies are required to verify our results.

Ethics Committee Approval: Ethics committee approval was received for this study from the ethics committee of Yıldırm Beyazıt University School of Medicine.
Informed Consent: Written informed consent was obtained from patients who participated in this study.

Peer-review: Externally peer-reviewed.

Author Contributions: Concept - A.F.Y., E.I.S., G.F.Y.A.; Design - A.F.Y., E.I.S., G.F.Y.A.; Supervision - A.F.Y., E.I.S., G.F.Y.A., H.L.K.; Resources G.F.Y.A., H.L.K., E.E.T., A.F.D.; Materials - H.L.K., E.E.T., A.F.D.; Data Collection and/or Processing - E.I.S., G.F.Y.A., E.E.T., A.F.D.; Analysis and/or Interpretation - H.L.K., E.E.T.; Literature Search - H.L.K., E.E.T., A.F.D.; Writing Manuscript - A.F.Y., E.I.S., G.F.Y.A., A.F.D.; Critical Review - A.F.Y., E.I.S., G.F.Y.A., H.L.K., E.E.T., A.F.D.

Conflict of Interest: No conflict of interest was declared by the authors.

Financial Disclosure: The authors declared that this study has received no financial support.

\section{References}

1. Ball RH, Caughey AB, Malone FD, Nyberg DA, Comstock $\mathrm{CH}$, Saade GR, et al; First and Second Trimester Evaluation of Risk (FASTER) Research Consortium. First and second- trimester evaluation of risk for Down syndrome. Obstet Gynecol 2007; 110: 10-7. [Crossref]

2. Smith R, Bischof P, Hughes G, Klopper A. Studies on pregnancy- associated plasma protein $\mathrm{A}$ in the third trimester of pregnancy. $\mathrm{Br} \mathrm{J}$ Obstet Gynaecol 1979; 86: 882-7. [Crossref]

3. Huynh L, Kingdom J, Akhtar S. Low pregnancy-associated plasma protein A level in the first trimester. Can Fam Physician 2014; 60: 899-903.

4. Kale İ, Gülerman HC, Moraloğlu Ö, Gürlek B, Yenicesu O, Sarıkaya $\mathrm{E}$, et al. Association between low levels of maternal serum PAPP$\mathrm{A}$ in the first trimester and complications of pregnancy. Turkiye Klinikleri J Gynecol Obst 2012; 22: 25-35. 
5. Spencer K, Cowans NJ, Molina F, Kagan KO, Nicolaides KH. First trimester biochemical markers of aneuploidy and the prediction of small-for-gestational age fetuses. Ultrasound Obstet Gynecol 2008; 31: 15-9. [Crossref]

6. Smith GC, Shah I, Crossley JA, Dobbie R. Pregnancy- associated plasma protein A and alpha-fetoprotein and prediction of adverse perinatal outcome. Obstet Gynecol 2004; 104: 30-6.

7. Ucella S, Colombo GF, Bulgheroni CM, Serati M, Bogani G, Salvatore $\mathrm{S}$, et al. First- trimester maternal serum screening and risk for fetal distress during labor. Am J Obstet Gynecol 2009; 201: 1661-6. [Crossref]

8. American College of Obstetricians and Gynecologists. Practice bulletin no. 116: Management of intrapartum fetal heart rate tracings. Obstet Gynecol 2010; 116: 1232-40. [Crossref]

9. Lin TM, Halbert SP, Kiefer D, Spellacy WN, Gall S. Characterization of four pregnancy-associated plasma proteins. Am J Obstet Gynecol 1974; 118: 223-36. [Crossref]

10. Hughes G, Bischof P, Wilson G, Klopper A. Assay of a plasental protein to detrmine fetal risk. BMJ 1980; 8: 671-3. [Crossref]
11. Lawrence JB, Oxvig C, Overgaard MT, Sotturp-Jensen L, Gleich GJ, Hays LG,et al. The insulin-like growth factor (IGF)-dependent IGF binding protein- 4 protease secreted by human fibroblasts is pregnancy-associated plasma protein-A. Proc Natl Acad Sci USA 1999; 96: 3149-53. [Crossref]

12. Smith GC, Stenhouse EJ, Crossley JA, Aitken DA, Cameron AD, Conner JM. Early pregnancy levels of pregnancy-associated plasma protein $\mathrm{A}$ and the risk of intrauterine growth restriction, premature birth, preclampsia and stillbirth. J Clin Endocrinol Metab 2002; 87: 1762-7. [Crossref]

13. Clemmons DR. Role of insulin-like growth factor binding proteins in controlling IGF actions. Mol Cell Endocrinol 1998; 140: 19-24. [Crossref]

14. Benian A, Uludağ S, Atiş A, Gök M, Madazli R. Analysis of umbilical cord blood acid-base status at birth. Cerrahpaşa J Med 2002; 33: 236-44.

15. Gilstrap LC, Hauth JC, Toussaint S. Second stage fetal heart abnormalities and neonatal acidosis. Obstet Gynecol 1984; 63: 209-13.

16. Paul RH, Suidan AK, Yeh S, Schifrin BS, Hon EH. Clinical fetal monitoring.VII. The evaluation and significance of intrapartum baseline FHR variability. Am J Obstet Gynecol 1975; 123: 206-10. [Crossref] 